\title{
The important role of information literacy and learning in the development of lifelong learners: How well prepared are our teachers and students?
}

\author{
Elizabeth Probert \\ Lecturer \\ University of Auckland \\ New Zealand
}

\begin{abstract}
There have recently been increasing numbers of published articles lamenting school students' lack of information literacy skills. All strongly state the urgent need for improvement. The problem may arise from classroom teachers' lack of knowledge of information literacy skills and their related pedagogical practice but there is little research. This presentation reports on a project, involving a cluster of New Zealand schools, which investigated both teacher's and students' understanding of information literacy and classroom practices. The results have established the need for better teacher understanding and practice. One solution will be to trial appropriate professional development.
\end{abstract}

Information literacy; lifelong learning; improving classroom practice

\section{Introduction}

The recent, rapid growth and enthusiastic uptake of the internet in education, with the corresponding avalanche of available information, has seen a much wider understanding of the importance of information literacy in the academic community. Until about ten years ago, journal articles reporting on the levels of information literacy skills in school students were all written by tertiary librarians or academics in tertiary library and information faculties (Bruce, 1997; Bruce, Candy \& Klaus, 2000; Doyle, 1994; Moore, 1999; Todd, 2000). Information literacy development was not addressed in any other arena. Today, academics from a variety of disciplines, and others from global organisations such as UNESCO (2006) have joined librarians in writing about the need to improve students' information literacy development (Combes, 2006; Walraven, Brand-Gruwel, \& Boshuizen, 2008).

The following definition of information literacy is accepted by many organisations (Association of American Colleges and Universities, 2002; Australian School Library Association, 2001; Education Review Office, 2005; Ministry of Education and National Library of New Zealand, 2002) and has been used throughout the project described in this presentation.

To be information literate, a person must be able to recognize when information is needed and have the ability to locate, evaluate, and use effectively the needed information. Information literate people are those who have learned how to learn. (American Library Association, 1998).

Students need to use a great number of skills when they are processing information. To complete assignments successfully, students need to define their information needs, formulate key questions and know how to locate, evaluate and use information from many sources including a variety of online resources. They need to be aware also of issues relating to the ethical use of information, such as 
copyright and plagiarism. Students who have been taught how to use a model or framework when carrying out such assignments will almost always be more successful than those with no such guidance (Kuhlthau, 2004; Todd, 2003a). Those who have not been taught the skills or provided with a framework for their research or inquiry often resort to copying and pasting material (Hipkins, 2005; Kuhlthau, Maniotes, \& Caspari, 2007; Moore, 2002; Todd, 2003b; Walraven et al., 2008).

While the literature highlights students' lack of information literacy skills, there is little work addressing reasons for this situation. Few researchers, for example, query how classroom teachers teach the skills or whether they teach them at all. Researchers such as Walraven, Brand-Gruwel and Boshhuizen (2008), working in the Netherlands point to teachers' lack of knowledge and their assumption that students will develop this skill "naturally" (p. 623). They also note, in their review of the literature, that information literacy "has been given little attention in schools" and is "rarely embedded in curricula" (p.624). Kirschner, Sweller \& Clark (2006) state that skills need to be taught and that "minimal guided instruction is likely to be ineffective" (p. 76), while Henri (2004) and Cass (2004), both from Australia, have pointed out that all classroom teachers need professional development in this area.

There is some evidence though, suggesting that teaching for information literacy, if the teachers have been appropriately trained, can be very effective. Lance $(2005,2006,2007)$ and Todd (2003), working with schools in USA, found that explicit teaching of skills, by trained school library teaching staff, makes a positive difference to student learning outcomes. A small action research project, carried out at a Wellington, NZ, high school, also demonstrated that careful and planned teaching for information literacy, does indeed make a difference (Hannah, 2005).

Information literacy development is also strongly linked to the development of life long learners, a common aim for many countries (Bruce, Candy, \& Klaus, 2000). According to Bryce \& Withers (2003), schools with a focus on lifelong learning should also have a strong focus on information literacy development. This, as Doyle (1994) points out, "is central to all successful learning and, by extension, to all successful living" (p. 44). de la Harpe \& Radloff (2000) assessed the characteristics of lifelong learners and described a number of information literacy strategies and skills that students need to develop in order to become effective learners. Bruce (2002) also refers to information literacy as the 'catalyst' needed to transform 'the information society of today into the learning society of tomorrow" (p. 4). In Singapore the government sees information skills as important to the Singapore economy, particularly with the growth of lifelong learning and knowledge-based industries (Hepworth, 2000).

\section{The New Zealand experience}

The recently published New Zealand Curriculum (Ministry of Education, 2007) emphasises the importance of lifelong learning and the Vision, (p.8), lists the attributes of lifelong learners. Such learners are "literate and numerate, critical and creative thinkers, active seekers, users and creators of knowledge and information decision makers". It can be seen that many of the skills underlying these attributes of lifelong learners are information literacy skills, even though this is not stated. If New 
Zealand schools are to develop lifelong learners, then these learners must develop good information literacy skills. The New Zealand government, while not explicitly linking information literacy with lifelong learning, does appear to appreciate the need for information literacy development. The Digital Strategy (Ministry for Economic Development, 2005), for example, aims to provide all "New Zealanders with ...the confidence to find and use the information they need" while the Ministry of Education's (2006) Enabling the $21^{\text {st }}$ century learner: An e-learning action plan for schools 2006-2010 states that there will be support for a focus on teacher professional development in information literacy development. While this has yet to eventuate, it does acknowledge the need.

There is evidence, in the meantime, that New Zealand students are not developing information literacy skills. Results from the New Zealand National Education Monitoring Project (NEMP) (Flockton, Crooks, \& White, 2006) suggest that the principles and goals of information literacy are not actually widely understood, supported or practised by the teaching profession. This project began in 1993 to assess and report on the achievement of Years 4 and 8 primary school students in New Zealand across all areas of the curriculum. Information skills were tested in 1997, 2001 and 2005 and analysis of the results found that there was little evidence of any change in the ability of year 4 and year 8 students to find and gather information between 1997 and 2005. Concerns listed in the 2006 report included the facts that more than $50 \%$ struggled to ask two or three 'strong' questions for an inquiry, even when working collaboratively. Students also lacked skills of discernment and discrimination in their use of internet information.

It is possible that this situation could improve if teachers received targeted training in how to teach these skills. Results from Slyfield's (2001, p.48.) survey of New Zealand schools found that " $90 \%$ of secondary schools indicated that less than half their teachers had taken some form of professional development relating to information literacy". She concluded that the research "showed a strong need for professional development for teachers...relating to information literacy" (p. 53). Hipkins (2005), when investigating 'research as a student learning activity' in six Wellington, New Zealand secondary schools, reports that students felt teachers had not taught them the skills they needed to carry out their own research projects. She also observed that much of what was termed research actually consisted merely of "information retrieval and repackaging" (p. 21).

The researcher was very pleased to become involved in the research project described in this presentation. This involves the collection of baseline data to assess teachers' and students' current understanding and practice of information literacy in order to establish whether or not both teachers and students in the schools have a good understanding of information literacy and the extent to which teachers are developing their students' skills. In future stages of the project, professional development will be designed, delivered and evaluated for teachers' and students' improvement of both knowledge and practice. 


\section{Method}

\section{Context}

Three schools, situated in the same Auckland suburb, formed a cluster and successfully applied to the Ministry of Education to obtain an Extending High Standards Across Schools (EHSAS) contract for three years. The cluster's stated aim is to empower students to become independent learners by placing the learner at the centre of the educational process with the focus on developing a policy for information literacy development school-wide, thereby extending creative and critical thinking skills. In the second phase of the project, professional development will be designed, delivered to teaching staff and evaluated. Each school has nominated two lead teachers to coordinate the current project which entails the collection and analysis of baseline data to establish the need for professional development. The gathering of further data in the second phase will allow for more statistical analysis to be carried out.

\section{Participants.}

A. coeducation intermediate school (Years 7 and 8 with students of 11 and 12 years of age),

B. state girls' high school Years 9-13 (students $13-17$ years of age).

C. integrated (Catholic) Years 8-13 girls' school (comprising both intermediate and high school age students from 11 to 17 years of age)

There were 121 female and 27 male teachers involved in the project. The gender distribution is not surprising given that the high schools are girls-only schools. The majority of the teachers, $60 \%$, were aged $30-49$ while a quarter were over 50 years of age and the remainder under 30 years of age. There was an even spread of the years respondents had been teaching, with most teaching for five -19 years. $86 \%$ had trained in New Zealand while the remainder were trained in UK, Australia, Canada, South Africa, India or Fiji. Those teaching at high school level represented all subject areas taught at the two secondary schools with the majority teaching subjects such as English, $41.4 \%$, mathematics, $37 \%$, science $22 \%$ and social sciences $14.4 \%$. These figures include those teaching at the intermediate level which was organised like the secondary schools with teachers specialising in subject areas.

\section{Design}

\begin{tabular}{|l|l|l|l|l|}
\hline $\begin{array}{l}\text { Feb-April } \\
2008\end{array}$ & $\begin{array}{l}\text { Online questionnaires } \\
\text { completed by } \\
\text { participants }\end{array}$ & Interviews & $\begin{array}{l}\text { Focus group } \\
\text { discussions (8 } \\
\text { groups) }\end{array}$ & Documentation \\
\hline $\begin{array}{l}\text { Students } \\
\text { Years 7- }\end{array}$ & $\begin{array}{l}\text { School A: 523, years 7 } 8 \\
10\end{array}$ & & $\begin{array}{l}\text { School A: year 7 \& } \\
\text { year 8 x2 }\end{array}$ & $\begin{array}{l}\text { Assignment work } \\
\text { sheets }\end{array}$ \\
& $\begin{array}{l}\text { School B: year 9 \& } \\
\text { School C: } 130, \text { years 8 }\end{array}$ & & \\
& $\& 9$ & year 10 x2 & \\
& 928 submitted & School C: year 9 & \\
\end{tabular}




\begin{tabular}{|l|l|l|l|l|}
\hline $\begin{array}{l}\text { Teaching } \\
\text { staff }\end{array}$ & $\begin{array}{l}\text { Teaching staff from all } \\
\text { schools (200) invited to } \\
\text { complete online } \\
\text { questionnaire. } \\
148(74 \%) \text { submitted }\end{array}$ & & $\begin{array}{l}\text { School A: Inquiry } \\
\text { Process from } \\
\text { classroom walls } \\
\text { School B: Inquiry } \\
\text { process for possible } \\
\text { use with cluster }\end{array}$ \\
\hline HoDs & & $\begin{array}{l}\text { Heads of } \\
\text { Departments } \\
\text { invited to } \\
\text { participate } \\
\text { School A: } 5 \\
\text { School B: } 5 \\
\text { School C: } 4\end{array}$ & & \\
\hline
\end{tabular}

Table 1: Design of project

The project comprised a mixed method design with the collection of quantitative data followed by the collection of qualitative (Creswell \& Plano Clark, 2007). Descriptive data were collected using questionnaires, interviews, focus group discussions and documentary data involving information literacy development and practice. Documents included worksheet templates, policies if any and departmental planning if any. Quantitative data using questionnaires were collected from those teachers and students involved in the project. In the intermediate school, data have therefore been collected from all staff and students. In both the secondary schools, one of which has an intermediate department, data have been collected from all teachers and from students in years $7-10$ (11years of age to 14 years of age). (See Table 1).

\section{Procedures}

Anonymous, online questionnaires were used with both teachers and students and were trialled using 2007 year 10 students who would not be involved in the project, and with teachers who knew they would not be returning to the schools in 2008. Both questionnaires used Likert-scale questions to gauge frequency or power of response. Open-ended questions were also included where, for example, respondents were asked to supply the attributes of an information literate person and, in a later question, to explain details of the model of information literacy processing that they used.

The term information literacy was used in this project as it is the term found in official documentation (Education Review Office, 2005; Ministry for Economic Development, 2005; Ministry of Education, 2002, 2004, 2006; Ministry of Education and National Library of New Zealand, 2002). Care was taken in both the teachers' and students' questionnaires and during interviews and discussion groups to link the term information literacy with other, possibly more recognisable terms, such as research and inquiry, commonly used in the schools. As these both involve the use of information literacy skills, it was hoped that participants would better understand the questions. 
Qualitative data were also gathered from voluntary interviews held with heads of departments (secondary schools) and team leaders or year level coordinators (intermediate school). They were therefore each responsible for between four and ten other teachers, representing, in all, around 70 teachers from most subject areas. The questions used in the interviews were designed to explore responses to parts of the questionnaire in order to gain a better understanding of professional develop needs. Interviewees were asked about their perceptions of information literacy and about their teaching practices concerning information literacy development. They were also asked to discuss any faculty policies and practices concerning information literacy.

Eight focus groups discussions were held, with students from year seven and year eight at the intermediate school and years nine and ten in the high schools. Students volunteered to attend when asked by the schools' project leaders, providing their parents had given written consent. Student were asked about their understanding of information literacy, about information processing models they used at school and about how they learned various skills.

The findings reported here are preliminary. Open-ended questionnaire responses and interview and focus group responses have been coded and sorted and further analysis of qualitative data is currently underway using NVivo7.

Triangulation was achieved through the collection and analysis of data from different and separate sources of evidence. Teaching staff self-reported through the use of the questionnaires, heads of departments have reported on teacher practice during interviews, students have reported on their own understanding and on the model of information-processing their teachers use in class. The documentation supplied examples of teachers' classroom assignments current information processing models in use.

\section{Results and discussion}

The response rate to the teacher questionnaire was high with 148 responses from a total of 200 teachers at the three schools (74\%). This was probably partly because the principals had carefully explained the aims of the project to staff and to the use of the online questionnaires. Teachers commented that they found this convenient as they all have laptops with wireless connections and so were able to complete the questionnaire whenever and wherever they found some time. Other commented included "I have lost some skills in writing for any time with a pen rather than with a keyboard" and that I "may have given much shorter answers if completing a conventional hard copy questionnaire".

928 students completed the online questionnaire, 523 from years seven and eight (11 and 12yrs of age), 384 from Year nine (13 yrs of age) and 21 from Year ten (14 yrs of age). Students completed the questionnaire in computer laboratories under supervision of their teachers who had been instructed not to allow conversations between students and not to offer advice or to provide answers. 
The findings address those questions in the teacher questionnaires which are most relevant to gauging teachers' understanding of information literacy, their classroom practice, skills assessment, teaching of skills and future developments. The interview questions explored these aspects in more depth. Student findings concentrated on questionnaire responses which indicated students' understandings, knowledge and classroom practice. The student focus group discussions explored these findings in more depth.

\section{How would you describe an information literate person?}

Questionnaires. Teacher and students responses to this question were coded and sorted according to the definition given at the start of the presentation. When asked to give the attributes of an information literate person, out of 128 responses, $23.4 \%$ had a focus on ICT, $30.4 \%$ had only one attribute (finding information), $10 \%$ supplied reasonable details but only $2.3 \%$ of responses demonstrated a full understanding as measured against the chosen definition. $7 \%$ of the responses had nothing to do with information literacy.

All but two students responded to this question if only to state that they did not know (42.2\%). Almost the same percentage, 43\%, gave an incorrect answer. The remaining $15 \%$ were only able to describe one or two aspects related to information literacy, usually finding information, and of those several associated information literacy only with ICT. The very small number (two only) of those who did not respond, contrasted with the large number of nil responses for other questions. Perhaps the position of this question near the beginning of the questionnaire accounts for the very low nil response as students were more enthusiastic to respond.

Interviews. When asked in the interviews to describe an information literate person, most teachers gave more informed responses than was apparent from the questionnaire responses. This was perhaps due to their greater teaching experience since they did hold positions of responsibility. Three replies were mostly concerned with the use of ICT rather than the use of a wide range of resources from all sources. Two teachers also emphasised the importance of recognising the need for information and 'articulating what it is they want to find out'. One teacher in particular, head of a large department, gave a very detailed response, describing many skills students would need to have when finding information. This description though did not go beyond finding information. All the teachers interviewed thought information literacy development was very important. "I think there's too much information out there and they just don't know how to access it effectively, otherwise it's too overwhelming for them", "That's one of the most important skills for the modern age", "They're all vital skills you all need".

Focus groups. In six of the eight groups, none of the students understood the term information literacy but several students associated it with research or inquiry. Two groups from the same class at one of the high schools appeared to understand noticeably more about information literacy than those in the other groups. It transpired that their teacher had, since the questionnaires had been completed, begun a series of lessons involving the research process and had been teaching information literacy skills. 


\section{Classroom practice}

Questionnaires, The majority of teachers indicated that they used an information processing model with their students when they were carrying out research assignments while the majority of students indicated they did not use a model when carrying research/ inquiry assignments, indicating a lack of communication between teachers and students. A chi- square test was calculated to look for differences across the groups and no significant differences were found.

A number of commonly used models were referred to in the questionnaire to help teachers and students answer the question, including two models which the lead teachers had said were used in the schools. However when teachers were asked to name (Fig.) and describe (Fig) the model they used, two thirds (66.8\%) did not reply while $3 \%$ said they did not know. $11.4 \%$ gave irrelevant answers such 'Inspiration', 'my model' or 'dot and jot' while only $18.2 \%$ named a recognizable model. Only $8 \%$ could fully describe the stages of the model they used. In reply to the same questions $80 \%$ of students did not reply. Only $3 \%$ named a recognizable model and even fewer, $1.4 \%$ (13 students), could describe the details of the model they named.

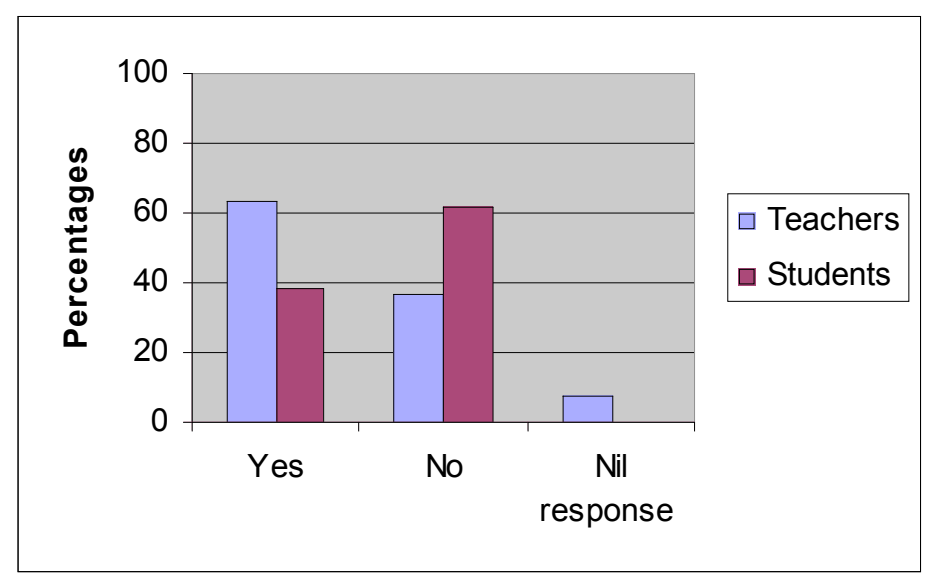

Fig. 1. I use a model with my students when they are carrying out research/inquiry assignments $n=148$

I use a model when completing research/inquiry assignments $n=921$ 


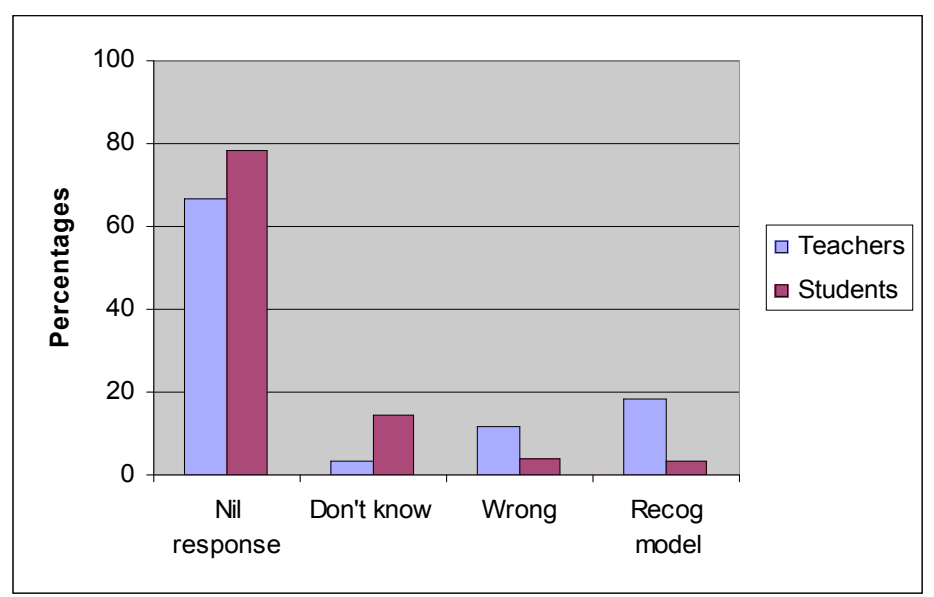

Fig. 2. The name of the model I use with my students $n=148$

I use when completing a research/inquiry assignment $n=921=$

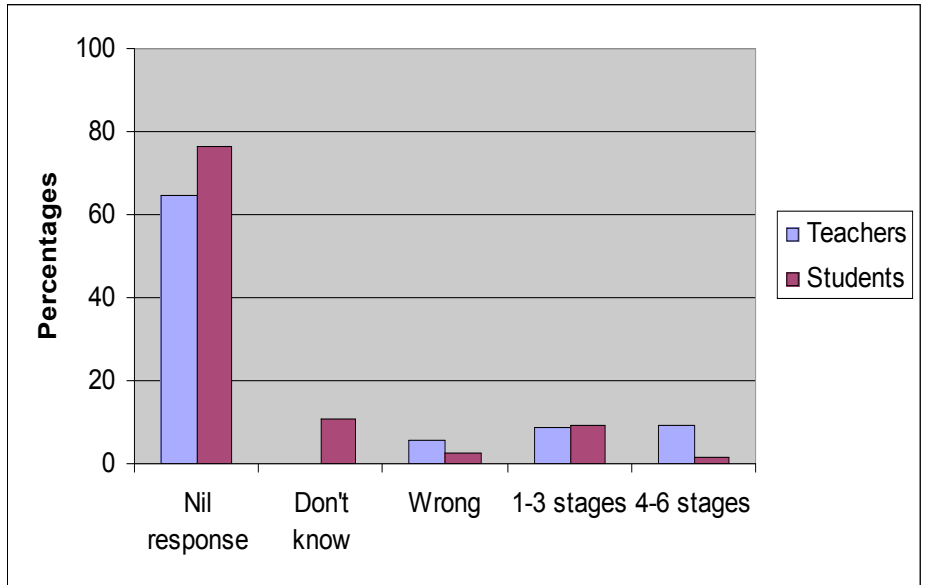

Fig. 3. The stages in the model I use with my students $n=148$

The stages of the model I use when completing a research/inquiry assignment $n=921$

Interviews and focus group discussions. These questionnaire findings were supported by teacher and student responses during the interviews and focus group discussions. All the teachers at one school said they did use a model and four named the model for inquiry learning that the lead teachers had designed for schoolwide use. None, though, could clearly name or describe the stages. Comments included "Can't remember the details", "The language keeps changing like immersion became ignition", "I use my own model. Each term I figure out what worked well and what didn't and discard any, just improve it really". The lead teachers were surprised that these teachers seemed unaware of the model, diagrams of which were in every classroom, particularly as teachers had had some training in using the model. It became obvious that, contrary to the lead teachers' expectations, the model was not being used in the way they had hoped or expected.

A similar situation was revealed with students from this school. Year seven students fresh from their former primary schools, were able to describe processes they had been taught to use at these previous schools and to refer to stages in the process such as defining or working out what they need to find out. Some referred to writing 'key questions' and using 'key words' when searching and to other skills. The year eight students from the same school, most of whom had attended the same primary schools as the year seven students, were not able to describe processes 
and skills and appeared to have forgotten previously taught skills. At the same time, they did not understand and use their current school's process. The students' teacher was really surprised to find that these students appeared to be so unfamiliar with this process she had assumed was well known and practised in the school.

It was interesting that most teachers took it for granted that students coming to intermediate or secondary schools already have good information literacy skills and do not check students' skills levels at the start of each year. Over half the teachers also thought the skills would develop naturally although, confusingly, $82 \%$ thought that the skills should be explicitly taught but presumably at previous schools or in other classes.

There was some evidence that explicit teaching of the skills may make a difference. This was seen in the replies from two groups of students from school B whose teacher had recently, since completion of the questionnaire, begun to teach them information skills and an accompanying process. These students, though, were surprised that they could use the same processing model in different subject areas, albeit with some small, appropriate adjustments. Other students who had not had any such teaching, did not refer to any process. Instead, they replied they would go straight to Google.

These are important findings as they have serious implications for the planned cluster-wide professional development. Those carrying out the professional development need to check that teachers really understand the process they are meant to teach. There is also a need for ongoing, professional development for teachers and it is also important to give students regular opportunities to practise the skills which can be forgotten if not practised regularly.

\section{Assessment of skills}

Questionnaires. Questionnaire responses indicated that $80 \%$ of the teachers in the survey never or rarely or only sometimes checked students' skills levels at the start of each year.

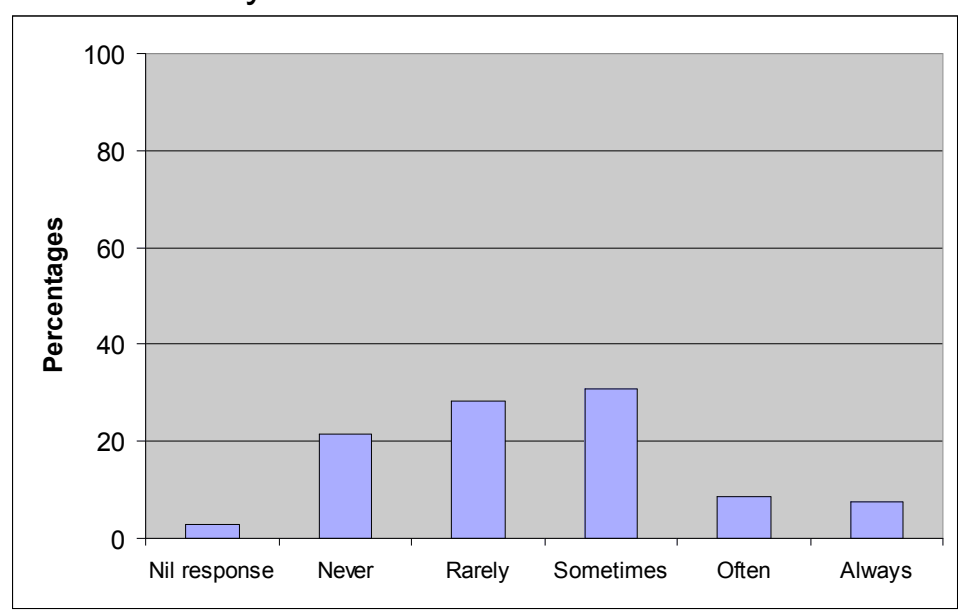

Fig. 4. I check the information literacy skills of my students at the start of each year $n=148$. 
Interviews. The interview responses supported this finding. None of the teachers interviewed checked the skills of students entering their schools although several acknowledged it would be a good idea to have such a system. Teachers commented that "You learn pretty quickly, your form teacher does and tells you of any kids with special needs or abilities, yeah, and you sort of just case by case, whatever kid needs help", "No formal technique we use and this sounds horribly hit and miss, pretty much by the end of four weeks with those students I could give you a pretty good idea of their ability and what sort of input they've had".

When asked if there were any systems in place for assessing skills either at the start of the year or after assignment work, the teachers all thought their schools did not have any such systems nor did their own departments/ teams. Several mentioned assessment for content only. There seemed to be some surprise at the question.

\section{Skill use and development}

Questionnaires. Teachers demonstrated from their questionnaire responses that they had some understanding of various information literacy skills in that most respondents did not confuse them with library skills and $83 \%$ agreed that information literacy skills need to be explicitly taught. There appeared to be some confusion with ICT skills and information literacy skills as $25 \%$ agreed that ICT skills and information literacy skills were the same while $27 \%$ were not sure.

When asked how often they modelled a number of skills to students, including brainstorming, mapping and presenting information and finding information from books and from online sources, around half $(50 \%)$ indicated that they did so often or always for most of these skills. The percentage of those modelling the use of online resources and of mapping and categorising information was a little lower at $42 \%$ and $44 \%$ respectively.

Students demonstrated some confusion when replying to similar questions about the use of ICT, when and how information literacy skills were used and information literacy skills and library skills. Two thirds of students indicated that they either did not know, or agreed that information literacy was mostly to do with ICT only. Over $50 \%$ of students either did not know or agreed that information literacy skills were only used when completing a research/inquiry assignment. More than $60 \%$ of students either did not know or agreed that information literacy skills were mostly about using libraries, in contrast to their teachers. 


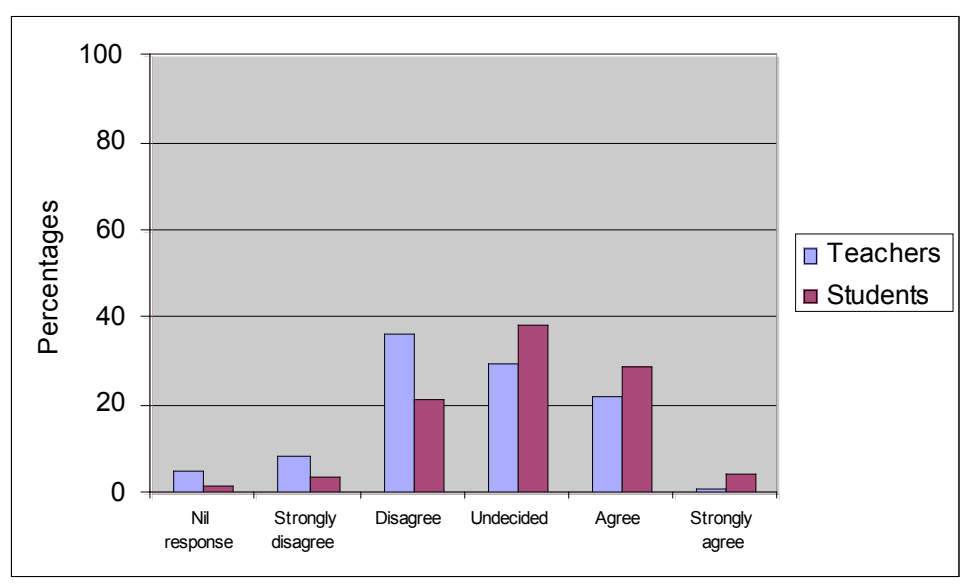

Fig. 5. Information literacy is mainly to do with ICT skills

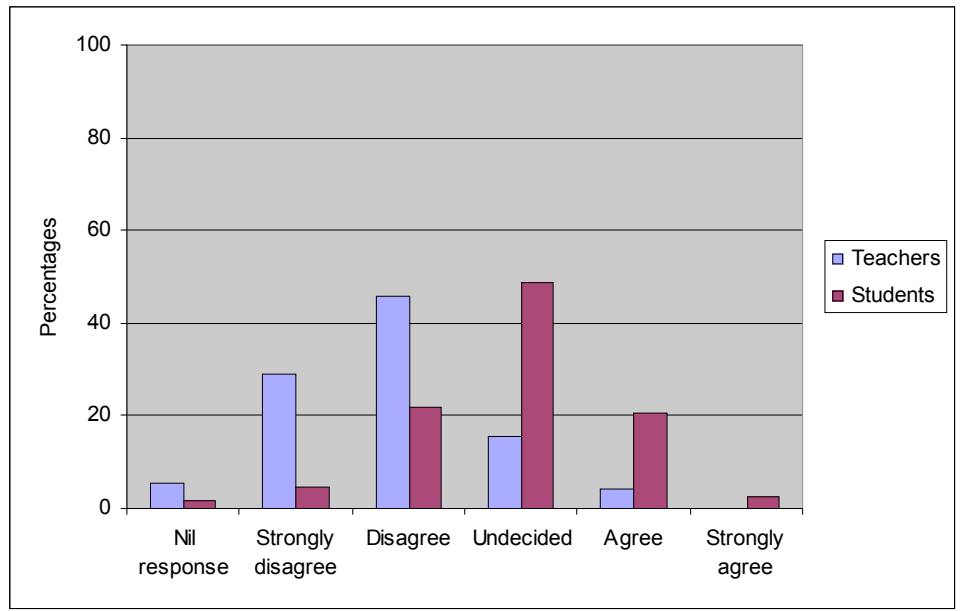

Fig. 6. Information literacy skills are the same as library skills

Interviews and focus group discussions. Teachers' questionnaire responses were not supported by responses from HODs who took part in the interviews. When asked 'How would you teach note taking, website evaluation, skimming and scanning?', only half the teachers could give a description, usually very vague of, for example, how they would teach note taking. One HOD thought a teacher in the department did explicitly teach skills but was not sure how this was done, and another gave details of teaching a dot and jot note taking method. "Most of us use the sort of dot and jot" but could provide few details. When asked about teaching website evaluation, one HOD thought it had been covered in the library and no teacher gave explicit details for teaching web site evaluation. Another HOD did comment that this 'might be good idea'. Few teachers could give any details about teaching students how to skim and scan various texts or visual images.

Students in the focus groups were asked about the skills they might need to use when carrying out inquiry assignments or research assignments. Most could not think of many skills beyond using Google without much prompting. These responses indicate a need for more explicit teaching of the skills.

\section{Future developments}


The majority of both teachers and students agreed that it would be helpful to a common method or model to use when doing research. The majority of teachers, $90 \%$, also though it would be helpful to have more strategies for teaching the skills and $75 \%$ of students would like their teachers to provide them with more skills. This was upheld by interview responses where the teachers all said they would welcome some sort of school wide planning for information literacy development and would really welcome professional development. Comments included "That would be really useful actually", "Yeah there's got to be a cohesion in what's happening across the school".

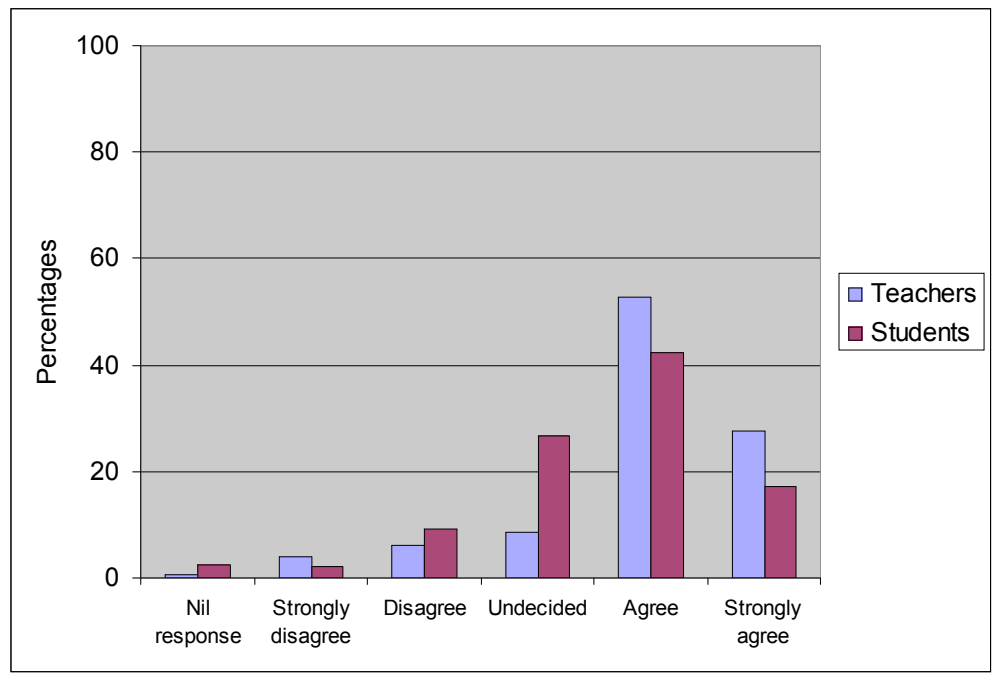

Fig. 7. It would be helpful to have a common method/ process $n=148$

I would like to have a plan/model I could use when dealing with information $n=921$

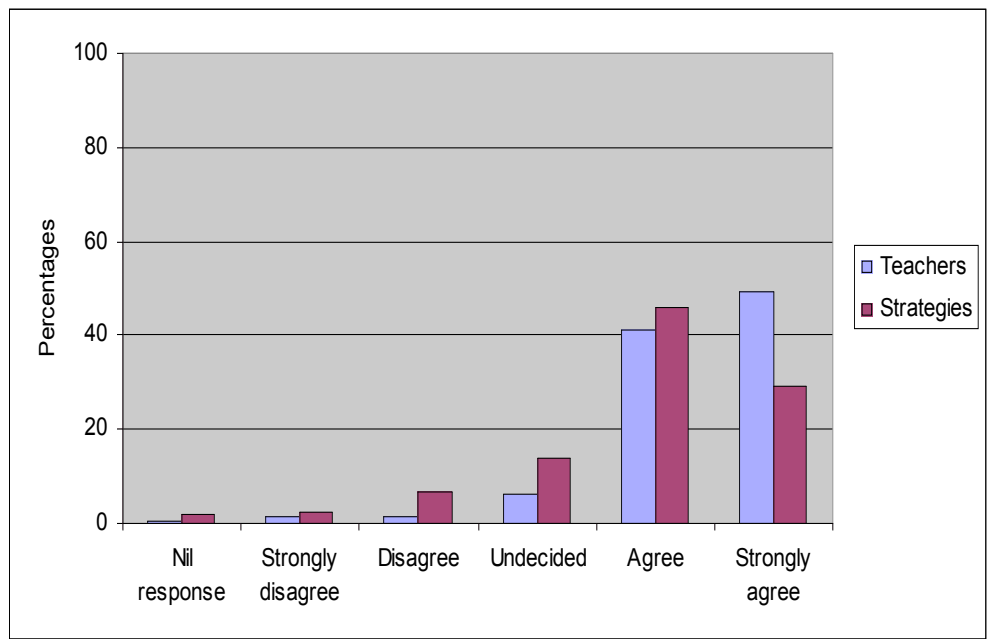

Fig. 8. It would be helpful to have more strategies for teaching skills $n=148$

It would be helpful if teachers taught us more ways to deal with information $n=921$

\section{Conclusions and recommendations}

It appears from this evidence gathered from questionnaire, interviews, discussions and documentation that few teachers from the three schools have much 
understanding of the term information literacy but some appeared to understand the concept. The term information literacy was frequently misunderstood by both teachers and students who usually connect it with literacy or reading or information and communications technology (ICT) whereas it actually embraces both literacy and ICT. Unfortunately it is not so easy to find a better term. It is also evident that a number of teachers in a variety of departments were not providing inquiry learning opportunities for students. There were several reasons given including time factors and that research was covered in other subject areas so they "didn't need to do it". Another reason given was that too many students simply "copied and pasted" but few teachers indicated that this might be because students needed more strategies to help them develop better skills. Even so, it was interesting that teachers, through the questionnaire and during interviews, were enthusiastic about adopting schoolwide methods of information processing and school-wide strategies for developing various skills and several stated how much they would welcome such training. Students too appeared to welcome the idea of being provided with more skills and processes for dealing with information.

The documentary evidence presented consisted of the inquiry model referred to above and several social studies units which involved students in research. None of these outlined methods of carrying out the research assignment. The work sheets and planning used by the one class which was familiar with information processing were designed and used after the teachers had been interviewed but before the focus group interviews. No departments had policies relating to information literacy development.

\section{Implications for planning and design of professional development.}

After analysing the baseline data collected, it is clear that there are a number of points to be taken into account when designing and delivering appropriate teacher professional development in the next phase of the project.

- Teacher knowledge does not necessarily equate to improved teaching.

- Almost all teachers appeared to support the need for professional development in this area. Lead teachers need to sustain this positive attitude.

- The model to be used should be simple and easy for teachers and students to understand. Lead teachers need to make sure that all the teachers do fully understand the model and take ownership of the process.

- Lead teachers need to model teaching strategies to teachers, explicitly teaching the skills so that the teachers in turn can explicitly teach skills to their students.

- Some form of assessment should be put in place to ensure that students are gaining the skills.

- Schools need to write policies and then plan for school-wide information literacy development at all year levels.

\section{References}


Association of American Colleges and Universities. (2002). Greater expectations: A new vision as a nation goes to college. Retrieved May 20, 2007 from http://www.aacu-edu.org/gex/index.cfm.

Australian School Library Association. (2001). Learning for the future: developing information services in schools (2nd ed.). Carlton, South Vic.: Curriculum Corporation.

Bruce, Candy, P., \& Klaus, H. (2000). Information literacy around the world: Advances in programs and research: Wagga Wagga, N.S.W: Charles Sturt University.

Bruce, C. (2002). Information literacy as a catalyst for educational change: A background paper. Retrieved February 20, 2007 from http://www.nclis.gov/libinter/infolitconf\&meet/papers/bruce-fullpaper.pdf.

Bryce, J., \& Withers, G. (2003). Engaging secondary school students in lifelong learning. Melbourne: Australian Council for Educational Research Ltd.

Cass, J. (2004). Developing an information literacy policy and program. Retrieved February 15, 2007 from http://www.asla.org.au/pubs/access/a index.htm.

Combes, B. (2006). Techno-savvy and all-knowing or techno-oriented? Information-seeking behaviour and the Net Generation? . Paper presented at the The multiple faces of literacy: Reading, knowing, doing. Proceedings of the 35th annual IASL Conference Lisbon, July 3-7.

Creswell, J., \& Plano Clark, V. (2007). Designing and conducting mixed methods research. Thousand Oaks, Calif.: SAGE Publications.

de la Harpe, B., \& Radloff, A. (2000). Informed teachers and learners: The importance of assessing the characteristics needed for lifelong learning. Studies in Continuing Education, 22(2), 169-182.

Doyle, C. (1994). Information literacy in an information society : a concept for the Information Age. Syracuse, N.Y.: ERIC Clearinghouse on Information \& Technology Syracuse University.

Education Review Office. (2005). Student learning in the information landscape. Wellington, New Zealand: Education Review Office.

Flockton, L., Crooks, T., \& White, J. (2006). Information skills: Assessment results 2005. Dunedin, New.Zealand: University of Otago.

Henri, J. (2004). Building an information literate school community: Putting teachers first. Paper presented at the Online Australian School Library Association (ASLA) conference: Constructing communities of literacy and learning

Hepworth, M. (2000). Developing information literacy programs in Singapore. In C. Bruce \& P. Candy (Eds.), Information literacy around the world: Advances in programs and research. (pp. 51-66): Wagga Wagga, New South Wales: Charles Sturt University.

Hipkins, R. (2005). Students' experience of researching in different subjects. set: Research information for teachers, 1, 18-22.

Kirschner, P., Sweller, J., \& Clark, R. (2006). Why minimal guidance during instruction does not work: An analysis of the failure of constructivist, discovery, problem-solving, experiential and inquiry-based teaching. Educational Psychologist, 4(2), 75-86.

Kuhlthau, C. (2004). Seeking meaning: A process approach to library and information services. Connecticut: Libraries Unlimited.

Kuhlthau, C., Maniotes, L., \& Caspari, A. (2007). Guided inquiry: Learning in the 21st century. Westport, Connecticut: Libraries Unlimited.

Ministry for Economic Development. (2005). The digital strategy: Creating our digital future. Wellington, New Zealand: Ministry for Economic Development.

Ministry of Education. (2002, 2004). Digital horizons: Learning through ICT. Wellington, New Zealand: Ministry of Education.

Ministry of Education. (2006). Enabling the 21st century learner: An e-learning action plan for schools, 20062010. Wellington, New Zealand: Learning Media.

Ministry of Education. (2007). New Zealand Curriculum. Wellington: Ministry of Education.

Ministry of Education and National Library of New Zealand. (2002). The school library and learning in the information landscape: Guidelines for schools. Wellington, New Zealand: Ministry of Education.

Moore, P. (2002). Information literacy: What's it all about? Wellington, New Zealand: New Zealand Council for Educational Research.

Probert, E. (2006). Developing information-literate students. Access, 20(1), 20-22.

Slyfield, H. (2001). Information literacy in New Zealand secondary and primary schools. Wellington, New Zealand: Research Unit National Library of New Zealand.

Todd, R. (2003a). Learning in the information age school: Opportunities, outcomes and options, Paper presented at IASL conference. Durban.

Todd, R. ( 2003b). Student learning through Ohio School Libraries: The Ohio research study. Retrieved January 4, 2007 from http://www.oelma.org/studentlearning/default.asp

UNESCO. (2006). Information literacy: Key for lifelong learning, from http://portal.unesco.org/ci/en/ev.php 
Walraven, A., Brand-Gruwel, S., \& Boshuizen, H. (2008). Information-problem solving: A review of problems students encounter and instructional solutions. Computers in Human Behaviour, 24(3), 623-648.

\section{Biographical Notes}

Elizabeth Probert lectures at the Faculty of Education, University of Auckland in the School of Arts, Languages and Literacies. Elizabeth is a trained teacher and teacher librarian and works with teachers enrolled in the Graduate Diploma in Education, specialising in information literacy and information and communication technologies as well as school library and classroom resource development.

\section{Statement of Originality}

This statement certifies that the paper above is based upon original research undertaken by the author and that the paper was conceived and written by the author alone and has not been published elsewhere. All information and ideas from others is referenced. 